\title{
The SPICE carbon isotope excursion in Siberia: a combined study of the upper Middle Cambrian-lowermost Ordovician Kulyumbe River section, northwestern Siberian Platform
}

\author{
ARTEM KOUCHINSKY*†, STEFAN BENGTSON*, YVES GALLET $\ddagger$, IGOR \\ KOROVNIKOV $\S$, VLADIMIR PAVLOV , BRUCE RUNNEGAR\|, GRAHAM SHIELDS\#, \\ JAN VEIZER**, EDWARD YOUNG $\|$ \& KAREN ZIEGLER $\|$ \\ *Department of Palaeozoology, Swedish Museum of Natural History, Box 50007, SE-104 05 Stockholm, Sweden \\ †Équipe de Paléomagnétisme, UMR CNRS 7154, Institut de Physique du Globe de Paris, France \\ $\S$ Institute of Petroleum Geology and Geophysics, Siberian Branch of Russian Academy of Sciences, Academician \\ Koptyug Avenue, 3, 630090 Novosibirsk, Russia \\ TInstitute of Physics of the Earth, Bol'shaya Gruzinskaya 10, Moscow 123995, Russia \\ ||Department of Earth and Space Sciences, University of California Los Angeles, CA 90095-1567, USA \\ \#Geologisch-Paläontologisches Institut, Westfälische Wilhelms-Universität, Correnstr. 24, 48149 Münster, Germany \\ **Ottawa-Carleton Geoscience Centre, University of Ottawa, Ottawa, ON K1N 6N5, Canada
}

(Received 2 April 2007; accepted 14 January 2008; First published online 23 May 2008)

\begin{abstract}
An integrated, high-resolution chemostratigraphic (C, O and $\mathrm{Sr}$ isotopes) and magnetostratigraphic study through the upper Middle Cambrian-lowermost Ordovician shallowmarine carbonates of the northwestern margin of the Siberian Platform is reported. The interval was analysed at the Kulyumbe section, which is exposed along the Kulyumbe River, an eastern tributary of the Enisej River. It comprises the upper Ust'-Brus, Labaz, Orakta, Kulyumbe, Ujgur and lower Iltyk formations and includes the Steptoean positive carbon isotopic excursion (SPICE) studied here in detail from upper Cambrian carbonates of the Siberian Platform for the first time. The peak of the excursion, showing $\delta^{13} \mathrm{C}$ positive values as high as $+4.6 \%$ and least-altered ${ }^{87} \mathrm{Sr} /{ }^{86} \mathrm{Sr}$ ratios of 0.70909 , is reported herein from the Yurakhian Horizon of the Kulyumbe Formation. The stratigraphic position of the SPICE excursion does not support traditional correlation of the boundary between the Orakta and Labaz formations at the Kulyumbe River with its supposedly equivalent level in Australia, Laurentia, South China and Kazakhstan, where the Glyptagnostus stolidotus and G. reticulatus biozones are known to immediately precede the SPICE excursion and span the Middle-Upper Cambrian boundary. The Cambrian-Ordovician boundary is probably situated in the middle Nyajan Horizon of the Iltyk Formation, in which carbon isotope values show a local maximum below a decrease in the upper part of the Nyajan Horizon, attributed herein to the Tremadocian Stage. A refined magnetic polarity sequence confirms that the geomagnetic reversal frequency was very high during Middle Cambrian times at 7-10 reversals per Ma, assuming a total duration of about $10 \mathrm{Ma}$ and up to 100 magnetic intervals in the Middle Cambrian. By contrast, the sequence attributed herein to the Upper Cambrian on chemostratigraphic grounds contains only 10-11 magnetic intervals.
\end{abstract}

Keywords: Cambrian, Ordovician, carbon, strontium, palaeomagnetism, stratigraphy.

\section{Introduction}

The Siberian Platform is one of the key areas in the world for research into the Cambrian-Ordovician interval. Continuous successions of sedimentary fossiliferous rocks little affected by metamorphism crop out there along river valleys. Three facies regions are traditionally recognized in the Cambrian of the Siberian Platform: Turukhansk-Irkutsk-Olyokma, Anabar-Sinsk and Yudoma-Olenyok (Rozanov et al. 1992). In the upper Cambrian these regions correspond respectively to the inner shelf, transitional (with reefs, banks and bars) and slope/basin depositional environments (Sukhov, 1997; Fig. 1). At the northwestern

†Author for correspondence: artem.kouchinsky@nrm.se margin of the platform the Cambrian deposits are often folded and well exposed in relatively compact sections. Among them, biostratigraphy of the upper Middle-Upper Cambrian of the classical Kulyumbe River reference section has been most extensively studied in the second half of the the 20th century (e.g. Rozova, 1963, 1964, 1968; Rozova \& Yadrenkina, 1967; Datsenko et al. 1968). This section, however, contains an endemic fauna that is a product of isolated environments at the margin of the inner shelf (Fig. 1). Without cosmopolitan genera and species of trilobites important for intercontinental correlation, faunal content and changes at Kulyumbe cannot be directly translated to global biostratigraphic events.

For the purpose of precise correlation, carbon isotopic stratigraphy is the most suitable method in 


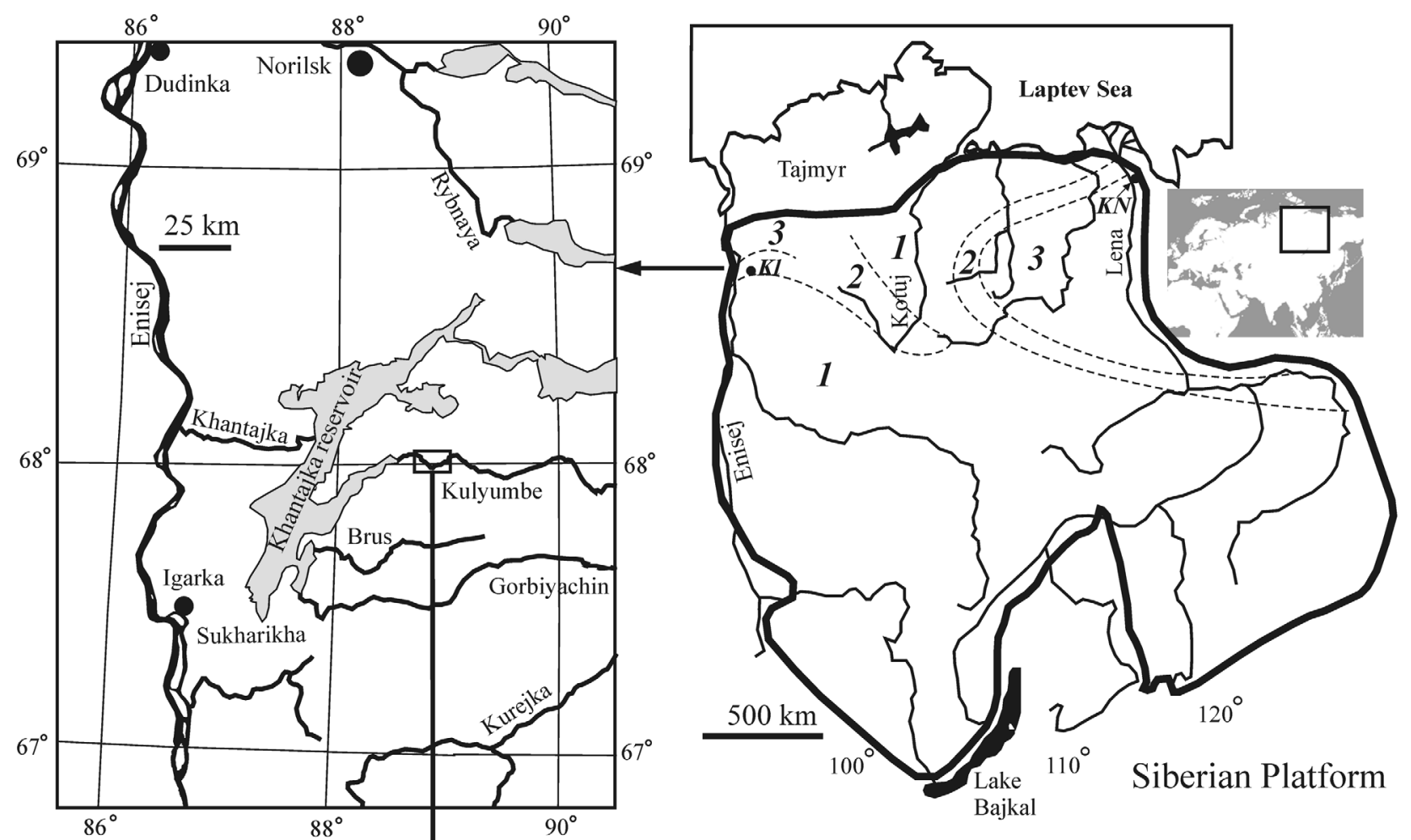

Sections: $\boldsymbol{K} \boldsymbol{l}$ - Kulyumbe, $\boldsymbol{K} \boldsymbol{N}$ - Khos-Nelege

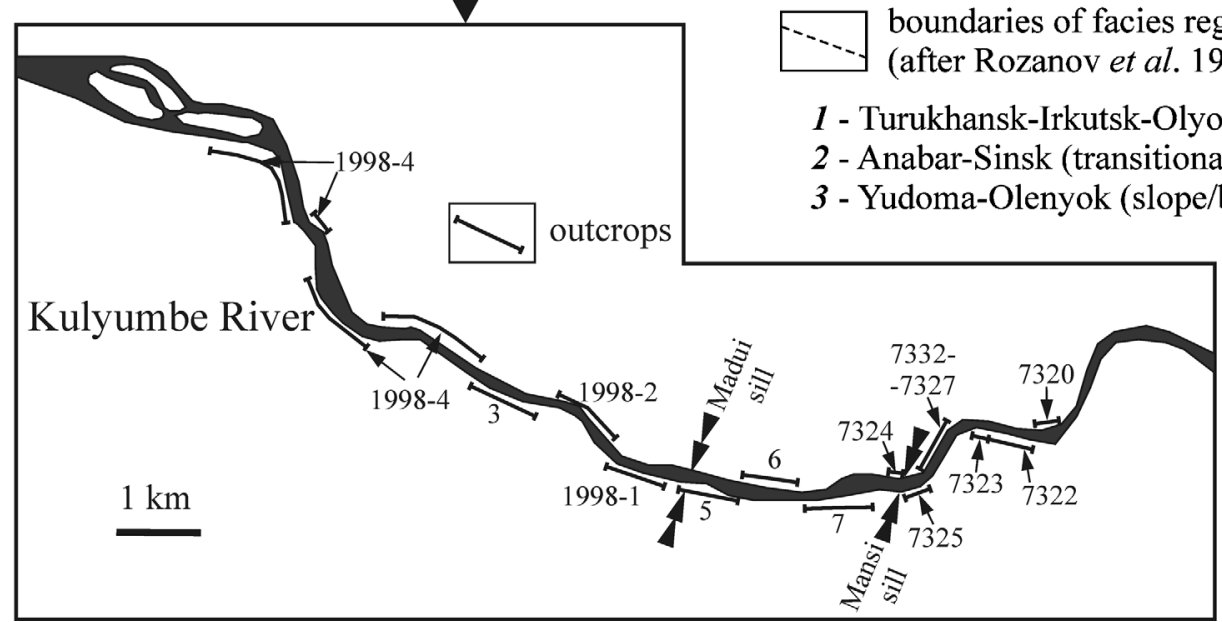

Figure 1. Location of the Kulyumbe section $(\mathrm{Ku})$ at the northwestern margin of the Siberian Platform, and other sections discussed. 7320, etc. - numbering of sampling profiles. Turukhansk-Irkutsk-Olyokma, Anabar-Sinsk and Yudoma-Olenyok facies regions in the upper Cambrian correspond respectively to the inner shelf, transitional (with reefs, banks and bars) and slope/basin depositional environments (Sukhov, 1997).

combination with biostratigraphy, but none of the areas on the Siberian Platform has been previously studied for carbon isotope chemostratigraphy within the upper Cambrian. This study provides the first high-resolution chemostratigraphic data from the upper Cambrianlowermost Ordovician of Siberia. The Steptoean positive carbon isotopic excursion (SPICE) is an excellent global chemostratigraphic marker in the upper Cambrian, usually rising far above the background noise (e.g. Saltzman et al. 2000, 2004). Documentation of the SPICE excursion from Siberia is valuable for correlation of richly fossiliferous Siberian sections with other well-known Cambrian sections globally, and therefore contributes much to understanding of biotic evolution, oceanography, climate, tectonics and magnetic field at this time in Earth history.

\section{Geological settings}

The isotopic profile presented in this paper derives from several outcrops along the Kulyumbe River, located $\sim 100 \mathrm{~km}$ E of the Enisej River $\left(\sim 68.0^{\circ} \mathrm{N}\right.$; $88.7-89^{\circ} \mathrm{E}$ ), at the northwestern margin of the 
Siberian Platform (Rozova, 1968, 1984; Sokolov, 1982; Rozanov et al. 1992; Pavlov \& Gallet, 1998, 2001) (Fig. 1). The Middle Cambrian-Lower Ordovician sediments are exposed along $\sim 10 \mathrm{~km}$ of the Kulyumbe River, including in ascending order: the Ust'-Brus, Labaz, Orakta, Kulyumbe, Ujgur and Iltyk formations (Fig. 2). These deposits are described in several published studies (e.g. Rozova, 1963, 1964, 1968, 1984; Rozova \& Yadrenkina, 1967; Datsenko et al. 1968).

The Ust'-Brus Formation, sampled through the upper $250 \mathrm{~m}$, is followed by $630 \mathrm{~m}$ of the Labaz Formation. They are characterized by grey, greenishgrey and reddish clayey and silty dolomitic lime mud/wackestones with algal boundstones, lenses of intraclast flat-pebble conglomerates, local cross-bedding and ripple marks.

The Orakta Formation comprises $450 \mathrm{~m}$ of grey and greenish-grey clayey and silty dolomitic lime $\mathrm{mud} /$ wackestones with lenses of bio-grainstones and packstones, algal boundstones, intraclast flat-pebble conglomerates, local cross-bedding, ripple marks and slump structures. Layers of breccia and megabreccia are developed in the lower part of the formation.

The Kulyumbe Formation is built of $645 \mathrm{~m}$ of grey, greenish-grey and reddish clayey and silty dolomitic and dolomitic lime mud/wackestones with grey algal boundstones, lenses of bio- and intraclast grainstones and packstones, intraclast flat-pebble conglomerates, local cross-bedding and ripple marks; slump structures occur in the lower and upper parts of the formation.

The overlying $210 \mathrm{~m}$ of the Ujgur Formation is represented by grey, greenish-grey and reddish clayey and silty dolomitic and dolomitic lime mud/wackestones with oolitic beds, algal boundstones and lenses of intraclast flat-pebble conglomerates. Slump structures and quartz-feldspar sandstone beds are reported from the lower part of the formation.

The lower $125 \mathrm{~m}$ of the Iltyk Formation (Nyajan Horizon) was sampled in the uppermost part of the studied section. It is composed of grey clayey and silty dolomitic and dolomitic lime mud/wackestones, grey and rare reddish dolo- mud/wackestones, as well as grey algal boundstones.

Folding and dislocations occur in the Kulyumbe section, where beds monoclinally dip at $15-25^{\circ} \mathrm{E}-$ SE. They are locally intruded by sills reflecting Carboniferous-Triassic tectonic activity at the margin of the Siberian Platform (Pavlov \& Gallet, 1998, 2001). These intrusions are not included in our stratigraphic column, but the positions of local marker horizons, such as the Madui and Mansi sills, are indicated by arrows (Figs 1,2). The Madui sill is $\sim 20 \mathrm{~m}$ thick in the river outcrop and located 15-20 $\mathrm{m}$ above the base of the Kulyumbe Formation (within the lowermost part of the Entsian Horizon according to Rozova, 1984). The Mansi sill is $\sim 60 \mathrm{~m}$ thick, and its base is situated $\sim 50 \mathrm{~m}$ above the base of the Ujgur Formation (base of the Mansian Horizon, after Rozova, 1984).

\section{Material and methods}

Approximately 1100 hand-samples were collected in 1995 and 1998 along the Kulyumbe River from several outcrops of the Ust'-Brus, Labaz, Orakta, Kulyumbe, Ujgur and Iltyk formations (Fig. 1) and studied for their remnant magnetization (Pavlov \& Gallet, 1998, 2001, 2005). The remaining fragments of these samples have been analysed for carbon and oxygen isotopes (Table 1 of Supplementary Material available online at http://pangaea.de and at http://www.cambridge.org/journals/geo). The samples were cut and the polished sections examined with a light microscope. A Dremel MiniMite micro-drill tool was used to extract rock powder from areas selected for their micritic composition. An amount of 200-400 $\mu \mathrm{g}$ was analysed from one or more spots (situated $\sim 1 \mathrm{~cm}$ apart) from each sample. Carbon and oxygen isotopes from the carbonates of the samples were analysed with a Finnigan MAT 253 equipped with a ThermoFinnigan Gasbench II at the Department of Earth and Space Sciences, University of California, Los Angeles. The carbon and oxygen isotope composition is expressed in the conventional $\delta^{13} \mathrm{C}$ and $\delta^{18} \mathrm{O}$ notations relative to V-PDB. Secondary standards used were NBS-19, IAEA-CO-1, IAEA-CO-8 and an internal laboratory standard, CARM-1.

The ThermoFinnigan Gasbench II enables a precision of the carbonate analyses that is better than $\pm 0.1 \%$ for carbon and oxygen, which is comparable to dual-inlet techniques typically used for such a purpose. Powdered samples were loaded into septum-capped $12 \mathrm{ml}$ glass vials (Labco exetainer) and placed into a heated block at $70^{\circ} \mathrm{C}$ (40 vials per run, including 6 vials with the secondary and in-house standards). The vials were then successively flush-filled with helium ( $\sim 6 \mathrm{~min} / \mathrm{vial})$, loaded with a few droplets of $100 \%$ orthophosphoric acid by a microlitre pump, and analysed using an autosampler $(\sim 20 \mathrm{~min} / \mathrm{vial})$. The time interval between the beginning of sample digestion by orthophosphoric acid and measurements of isotope ratios in the resulting $\mathrm{CO}_{2}$ gas was $\sim 80 \mathrm{~min}$.

Concentrations of major and trace elements (see Table 2 of Supplementary Material) were measured with ICP-OES (Varian Vista Pro Ax) at the Department of Geology and Geochemistry, Stockholm University. Rock powder samples of $50 \mathrm{mg}$ were dissolved in $2.5 \mathrm{ml}$ ultrapure $7 \mathrm{M} \mathrm{HNO}_{3}$. After addition of distilled water, the final volume of solution in each vial reached $50 \mathrm{ml} . \mathrm{Mn} / \mathrm{Sr}$ and $\mathrm{Mg} / \mathrm{Ca}$ ratios are used to estimate meteoric alteration and dolomite component of carbonates, respectively. These proxies were analysed from the Kulyumbe, Ujgur and Iltyk formations, where dolostones abound and alternate with limestones.

Geochemical data from 70 additional samples collected in 1994 along the same Kulyumbe River section are also presented here (Table 3 of Supplementary Material). These samples were collected by Stefan Ebneth and analysed for $\mathrm{C}, \mathrm{O}$ and $\mathrm{Sr}$ isotopes as well as trace element concentrations at the Ruhr-Universität 


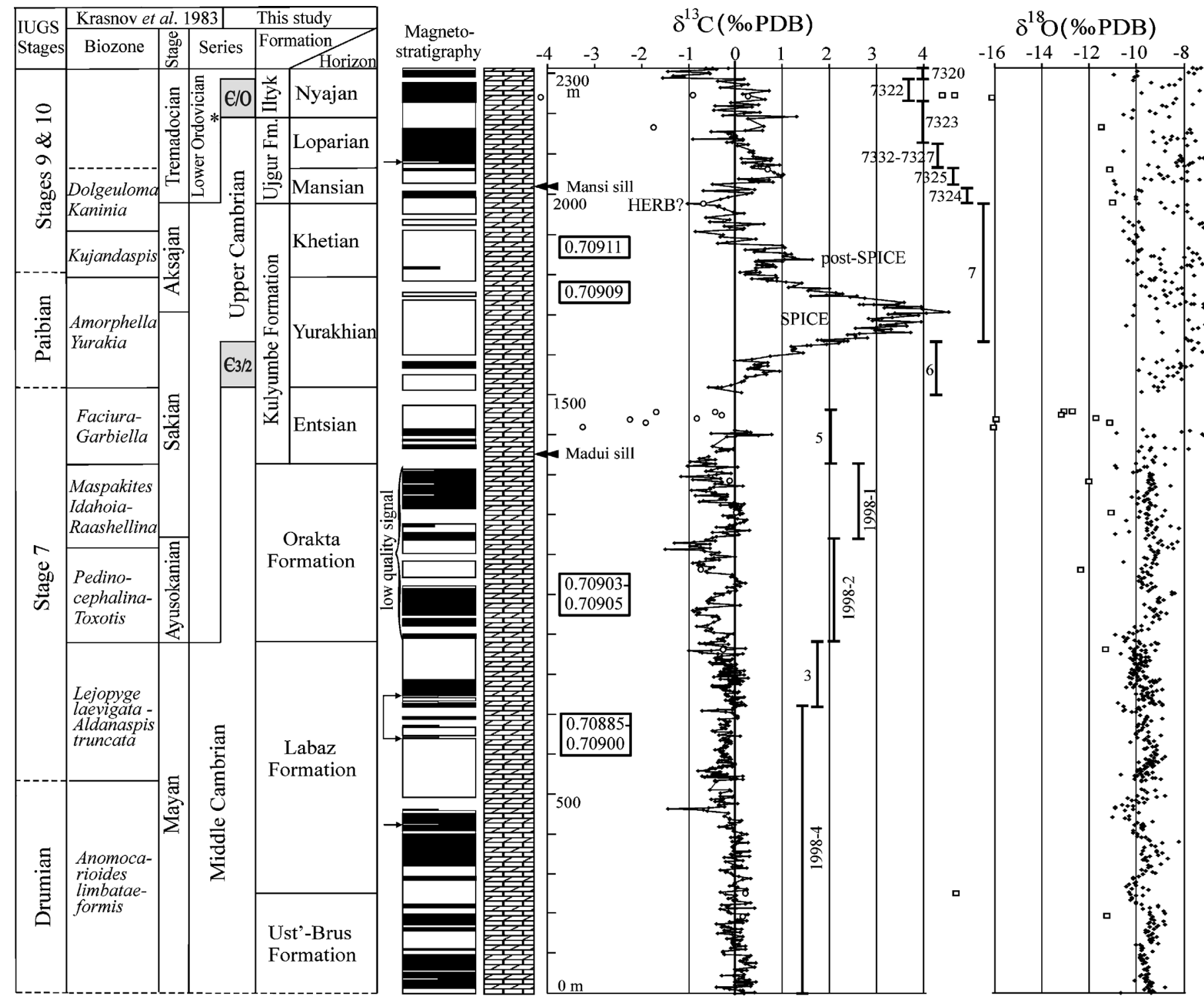

Clay-silty limestones and dolostones with algal boundstones, intraclast conglomerates, local

Cambrian-Ordovician boundary interv $\epsilon_{3 / 2}$ Upper-Middle Cambrian boundary interval
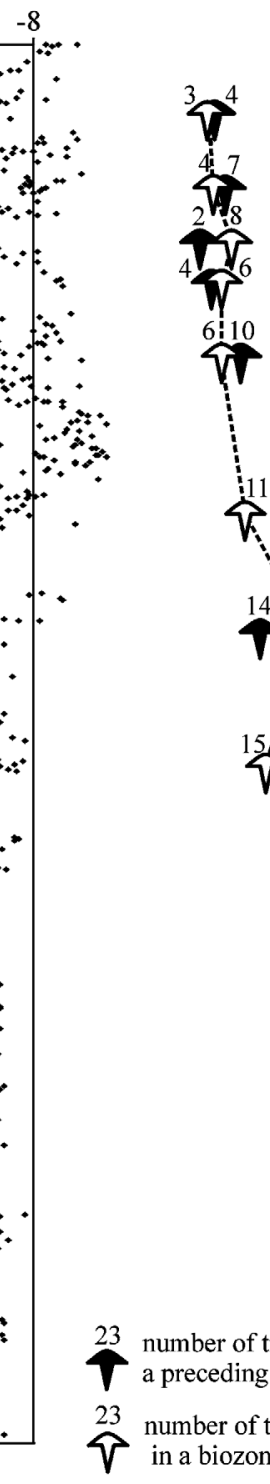

$\stackrel{11}{23}$
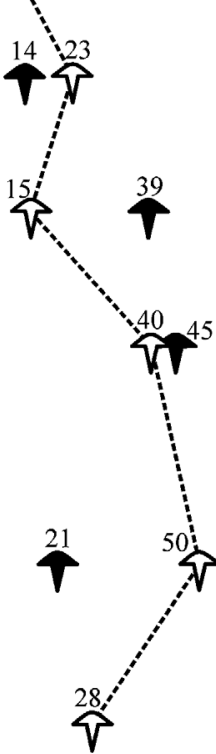

umber of trilobite species from a preceding biozone absent (extinct) 23 number of tritobi $\checkmark$ in a biozone

0.70909 intervals with ${ }^{87} \mathrm{Sr}{ }^{88} \mathrm{Sr}$ values

Figure 2. $\delta^{13} \mathrm{C}$ and $\delta^{18} \mathrm{O}$ profiles, ${ }^{87} \mathrm{Sr}{ }^{86} \mathrm{Sr}$ data, magnetostratigraphy and changes in associations of trilobites through the upper Middle Cambrian-lowermost Ordovician strata of the Kulyumbe section. 7320, etc. as in Figure 1. Samples with $\delta^{18} \mathrm{O}<-11 \%$ may possibly be altered during diagenesis and are shown as open circles $\left(\delta^{13} \mathrm{C}\right.$ curve $)$ and rectangles $\left(\delta^{18} \mathrm{O}\right.$ curve). ${ }^{87} \mathrm{Sr} /{ }^{86} \mathrm{Sr}$ values refer to 'best-preserved' samples with $\mathrm{Mn} / \mathrm{Sr}<0.5$ and $\mathrm{Mg} / \mathrm{Ca}<0.04$ only (see text). ${ }^{*}$ - Rozova $(1968,1984$ ) placed the Cambrian-Ordovician boundary at the base of Nyajan Horizon (names of horizons given by Rozova 1968, 1984). Single-sample polarity zones are shown by half bars in the magnetostratigraphic column. 
Bochum between 1995 and 2001 (hereafter referred to as the Ottawa-Bochum dataset).

For $\mathrm{Ca}, \mathrm{Mg}, \mathrm{Mn}, \mathrm{Fe}$ and $\mathrm{Sr}$ contents of the 1994 samples, $5-10 \mathrm{mg}$ of powdered sample were dissolved in $10 \mathrm{ml}$ of $2 \% \mathrm{HCl}$ and analysed using a Varian AA 300 Atomic Absorption Spectrometer. The same powders were used for isotopic analyses. For stable isotopes, $1-5 \mathrm{mg}$ of sample was reacted offline with $100 \%$ orthophosphoric acid at $50{ }^{\circ} \mathrm{C}$ and analysed using a Finnigan 251 mass spectrometer. Analytical reproducibility for both $\delta^{13} \mathrm{C}$ and $\delta^{18} \mathrm{O}$ was within $0.1 \%$.

$\mathrm{Sr}$ isotope analyses were carried out on acetic acid leachates after an initial preleach with $0.01 \mathrm{~N} \mathrm{HCl}$, which removed up to $10 \%$ of the sample. Leaching experiments were carried out to test the efficacy of this technique (see below). Standard techniques were used to concentrate $\mathrm{Sr}$ for analysis (Ebneth et al. 2001; Shields et al. 2003), and measurements were done on a Finnigan 262 thermal ionization mass spectrometer under the supervision of D. Buhl. International standard NBS SRM 987 yielded 0.710231, which represents the mean value over 4.5 years and 550 measurements with a standard deviation ( $1 \mathrm{SD}$ ) of $38 \times 10^{-6}$ and a standard error of $17 \times 10^{-6}$.

Five bulk limestone powders (K15, K17, K19, K20 and K21) were selected arbitrarily to test the efficacy of the strong acid preleach (Table 4 of Supplementary Material). They were all prepared in identical fashion. Initially, they were washed in a dilute solution of $\mathrm{HCl}$ $(0.01 \mathrm{~N})$, the supernate being retained for analysis. Thereafter, the residue was dissolved in $1 \mathrm{M}$ acetic acid. The same powders were also prepared without any preleach using $1 \mathrm{M}$ acetic acid and $2.5 \mathrm{~N} \mathrm{HCl}$ in separate experiments. The preleach was more radiogenic than the subsequent acetic acid leach in all five cases, with the difference ranging from $9 \times 10^{-6}$ to $86 \times 10^{-6}$. In two out of five instances, the preleach was also significantly more radiogenic than the $2.5 \mathrm{~N}$ $\mathrm{HCl}$ bulk carbonate leach. In every case, the preleached $1 \mathrm{M}$ acetic acid procedure yielded a less radiogenic ratio than the non-leached acetic acid procedure; however, the difference was only statistically significant in one case out of five, Ku $19\left(39 \times 10^{-6}\right)$.

\section{Results of the geochemical analyses}

The Kulyumbe profile exhibits $\delta^{13} \mathrm{C}$ values which plateau around zero through the upper Ust'-Brus and Labaz formations, followed by a decreasing trend that includes minor oscillations with a peak-to-peak amplitude of $1-2 \%$ in the Orakta and lowermost Kulyumbe formations (Fig. 2). In the Yurakhian Horizon of the Kulyumbe Formation, the $\delta^{13} \mathrm{C}$ values rise as high as $+4.6 \%$ and then drop, showing the characteristic features of the worldwide SPICE excursion (Fig. 2). The excursion in the Kulyumbe section is defined by $>70$ samples and extends through $\sim 200 \mathrm{~m}$ of carbonate rock. Previously, the excursion was recognized in the same section on the basis of five samples only (S. Ebneth \& J. Veizer, unpub. data; Table 3 of Supplementary Material). A smaller positive $\delta^{13} \mathrm{C}$ peak with amplitude of $\sim 1.5 \%$ is observed immediately above the SPICE excursion, in the lower Khetian Horizon of the Kulyumbe Formation ('postSPICE' in Fig. 2). The $\delta^{13} \mathrm{C}$ values then decrease in an oscillatory fashion towards the lower boundary of the Ujgur Formation. At the boundary between the Kulyumbe and Ujgur formations, $\delta^{13} \mathrm{C}$ values reach a minimum of $\sim-1 \%$, before rising in the Ujgur Formation. They peak at $\sim 1 \%$ in the upper Mansian Horizon and drop to $\sim 0 \%$ in the upper Loparian Horizon (Fig. 2). In the uppermost Loparian and in the Nyajan Horizon of the Iltyk Formation, the values oscillate near $0 \%$ and drop to $\sim-1 \%$ in the upper Nyajan Horizon.

Trace element and oxygen isotope characteristics may help to assess the state of preservation of carbonate $\delta^{13} \mathrm{C}$ and ${ }^{87} \mathrm{Sr} /{ }^{86} \mathrm{Sr}$ values. Most of the samples show $\delta^{18} \mathrm{O}$ values between $-6 \%$ and $-11 \%$. However, carbonates of the upper Entsian Horizon of the Kulyumbe Formation as well as several samples from other parts of the section yielded anomalously low $\delta^{13} \mathrm{C}$ and $\delta^{18} \mathrm{O}$ values. In sedimentary carbonates, very low $\delta^{18} \mathrm{O}$ values can result from a diagenetic resetting of $\delta^{18} \mathrm{O}$ (Kaufman \& Knoll, 1995). Although $\delta^{13} \mathrm{C}$ is much less prone to diagenesis than $\delta^{18} \mathrm{O}$, anomalously low oxygen isotope ratios are commonly associated with alteration of the carbon isotopic record as well. Therefore, samples with $\delta^{18} \mathrm{O}<-11 \%$ are considered herein with caution, because they are possibly altered, and are shown as open circles $\left(\delta^{13} \mathrm{C}\right.$ curve $)$ and rectangles $\left(\delta^{18} \mathrm{O}\right.$ curve $)$ in Figure 2. All samples analysed show $\mathrm{Mn} / \mathrm{Sr}<10$, except for sample K473 $(\mathrm{Mn} / \mathrm{Sr}=12)$ from the Yurakhian Horizon (Fig. 3). Although this sample might be excluded as probably altered (e.g. Kaufman \& Knoll, 1995), its $\delta^{13} \mathrm{C}$ and $\delta^{18} \mathrm{O}$ values of respectively $+3.16 \%$ and $-7.15 \%$ are not anomalous.

Carbon isotope values from the earlier OttawaBochum dataset (Table 3 of Supplementary Material) are consistent with the higher resolution dataset herein, and with published data from Siberia (Brasier \& Sukhov, 1998). Oxygen isotope values, however, are more internally consistent in the Ottawa-Bochum dataset, showing a clear trend towards more ${ }^{18} \mathrm{O}$ depleted values up-section (Fig. 2; Tables 1 and 3 of Supplementary Material). This difference would appear to reflect mineralogy, in that the smaller OttawaBochum study used selected calcitic samples only, while the more variable $\delta^{18} \mathrm{O}$ values of the upper Kulyumbe section studied herein seem likely to reflect variable degrees of dolomitization in that part of the high-resolution profile (Fig. 2). This interpretation is supported by the fact that $\mathrm{Mg} / \mathrm{Ca}, \mathrm{Mn} / \mathrm{Sr}$ ratios and $\delta^{18} \mathrm{O}$ (Fig. 3) show positive correlation (positive outliers in $\delta^{18} \mathrm{O}$ are all partially dolomitized).

$\mathrm{Sr}$ isotope ratios range from 0.708732 to 0.709171 through the interval of the Middle Cambrian Mayan Stage to the Cambrian-Ordovician boundary (Table 3 

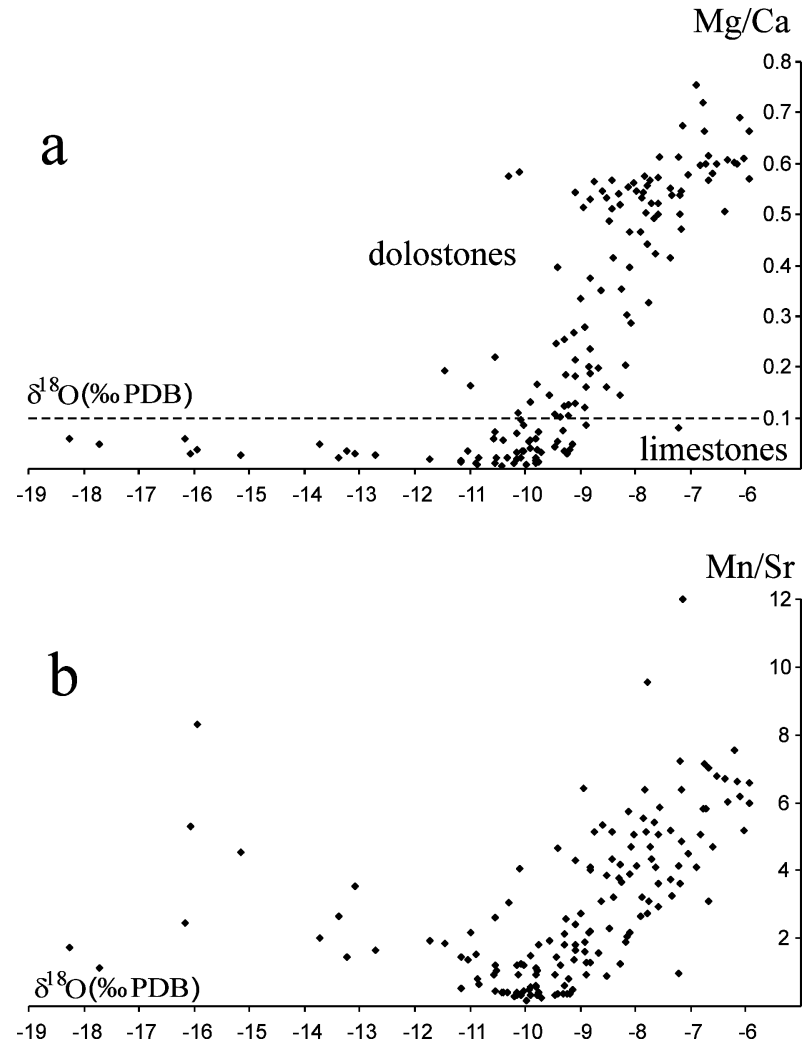

Figure 3. $\mathrm{Mg} / \mathrm{Ca}$ (a) and $\mathrm{Mn} / \mathrm{Sr}$ (b) against $\delta^{18} \mathrm{O}$ plots showing association of increasing dolomite content with higher $\delta^{18} \mathrm{O}$ and elevated $\mathrm{Mn} / \mathrm{Sr}$.

of Supplementary Material). In general, ratios rise through the Middle to Upper Cambrian. The generally negative correlation in older samples between $\mathrm{Mn} / \mathrm{Sr}$ (and $\mathrm{Mg} / \mathrm{Ca}$, in Atdabanian samples only) and ${ }^{87} \mathrm{Sr} /{ }^{86} \mathrm{Sr}$ indicates that uppermost values, unusually, may best approximate contemporaneous seawater ${ }^{87} \mathrm{Sr} /{ }^{86} \mathrm{Sr}$ through the lower half of the section. By contrast, the positive correlation between $\mathrm{Mn} / \mathrm{Sr}$, $\mathrm{Mg} / \mathrm{Ca}$ and ${ }^{87} \mathrm{Sr} /{ }^{86} \mathrm{Sr}$ ratios, as well as the generally high consistency of isotope values through the SPICE interval, indicate a well-preserved ${ }^{87} \mathrm{Sr} /{ }^{86} \mathrm{Sr}$ ratio of 0.709095 for that level. Data scatter is reduced when only the ${ }^{87} \mathrm{Sr} /{ }^{86} \mathrm{Sr}$ ratios of samples below suitable diagenetic cut-off points are considered. If only samples with $\mathrm{Mn} / \mathrm{Sr}<0.5$ and $\mathrm{Mg} / \mathrm{Ca}<0.04$ are included, as being considered to be least altered (Fig. 2), then ${ }^{87} \mathrm{Sr} /{ }^{86} \mathrm{Sr}$ changed from $0.70885-0.70900$ in the Middle Cambrian Labaz Formation to 0.709030.70905 in the Orakta Formation, and then to higher values of 0.70909-0.70911 in the Upper Cambrian Kulyumbe Formation.

\section{The Middle-Upper Cambrian boundary in the Kulyumbe section}

Traditionally, the Middle-Upper Cambrian boundary on the Siberian Platform has been placed at the top of the Lejopyge laevigata-Aldanaspis truncata Biozone of the Mayan Stage (Rozanov et al. 1992, Geyer \& Shergold, 2000; Fig. 2). In the Kulyumbe section this level is usually traced to the boundary between the Labaz and Orakta formations (Rozova, 1963, 1964, 1968, 1984) and coincides with the base of the Pedinocephalina-Toxotis Biozone (Krasnov etal. 1983; Fig. 2). The ratification by the International Union of Geological Sciences of the MiddleUpper Cambrian boundary between the Glyptagnostus stolidotus and G. reticulatus biozones in the Paibi section on the South China Platform (Peng et al. 2004; Fig. 4) requires that the traditional position of this boundary on the Siberian Platform be changed accordingly.

Khos-Nelege, situated on the northeastern Siberian Platform (Fig. 1), is the reference section through the Middle-Upper Cambrian boundary in Siberia (Lazarenko \& Pegel', 2001). In this section, the boundary is now placed at the base of the Glyptagnostus reticulatus-Eugonocare (Olenaspella) evansi Biozone (Lazarenko \& Pegel', 2001; Fig. 5). The Khos-Nelege section is associated with deeper-water basin/slope facies (Fig. 1) and cosmopolitan trilobites (for the purposes of this paper, the term 'trilobites' also includes agnostids). By contrast, the Middle-Upper Cambrian transitional strata of the Kulyumbe section were deposited on the carbonate platform, in inner shelf environments (Fig. 1), where almost all the trilobites are endemic (Rozova, 1963, 1964, 1968, 1984; Rozanov et al. 1992; Sukhov, 1997; Varlamov, Pak \& Rozova, 2006). Therefore, biostratigraphic correlation between these two sections is difficult, and alternative methods, such as chemostratigraphy, are needed.

No major $\delta^{13} \mathrm{C}$ oscillations are revealed from the upper Ust'-Brus, Labaz and Orakta formations, correlated herein with the upper part of the Mayan Stage (Fig. 2). This is in agreement with data from Brasier \& Sukhov (1998) showing a plateau during this interval from the Siberian Platform and with the values oscillating near zero in Laurentia, reported by Saltzman (2005), and China (Zhu et al. 2004; Peng et al. 2006). Mild oscillations in the Ust'-Brus and Labaz formations (Fig. 2 herein) are similar to those shown by Peng et al. (2006, figs 6, 7) from the Lejopyge laevigata Zone and upper Drumian Stage of China. The upper Stage 4-lowermost Drumian Stage interval in China (Zhu et al. 2004, figs 2, 3, 6; Peng et al. 2006, fig. 7; Zhu, Babcock \& Peng, 2006), as well as the traditional Middle Cambrian of Laurentia (Montañez et al. 2000) show pronounced oscillations, probably present in the lower Mayan and Amgan stages of the Middle Cambrian of Siberian Platform (Brasier \& Sukhov, 1998; A. Kouchinsky, unpub. obs.). According to biostratigraphic correlation (Geyer \& Shergold, 2000; Babcock et al. 2005; Peng et al. 2006), these excursions belong, however, to an interval below the profile sampled at Kulyumbe.

In addition to Siberia, the SPICE excursion has been documented from Laurentia (Saltzman, Runnegar \& Lohmann, 1998; Saltzman et al. 1995, 2000, 2004; Glumac \& Walker, 1998; Buggisch, in press), Australia (Saltzman et al. 2000), Kazakhstan (Saltzman et al. 


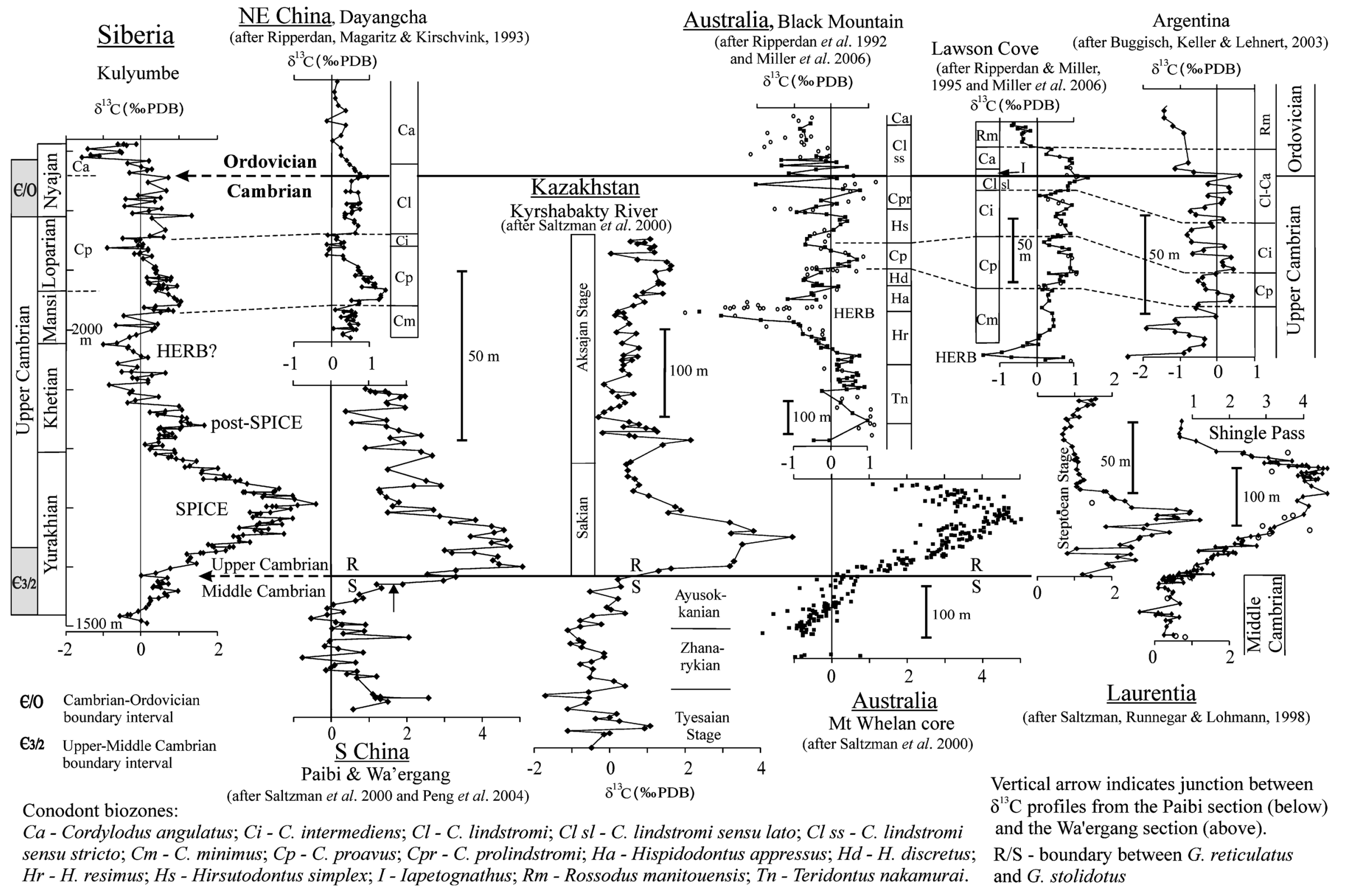

Figure 4. Global correlation of the Upper Cambrian-lowermost Ordovician part of the Kulyumbe section. Open circles show samples possibly altered by diagenesis as indicated by the authors, and/or by $\delta^{18} \mathrm{O}<-11 \%$ data, where available. Occurrence of Cordylodus proavus $(\mathrm{Cp})$ and C. angulatus $(\mathrm{Ca})$ in the Kulyumbe section according to Tesakov et al. (2003). 


\begin{tabular}{|c|c|c|c|}
\hline & Horizon & Biozone & Series \\
\hline & \multirow{3}{*}{ Khos-Nelegerian } & Parabolinites levis & \multirow{6}{*}{ 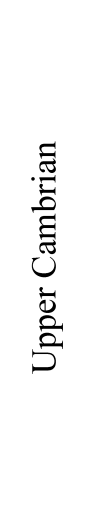 } \\
\hline & & $\begin{array}{l}\text { Parabolinites rectus } \\
\text { Acerocare tullbergi }\end{array}$ & \\
\hline.$\stackrel{0}{\overparen{\Xi}}$ & & Plicatolina perlata & \\
\hline E & \multirow{3}{*}{ Kutugunian } & Cedarellus felix & \\
\hline t̆ & & Irvingella & \\
\hline 8 & & $\begin{array}{l}\text { Glyptagnostus reticulatus } \\
\text { Olenaspella evansi }\end{array}$ & \\
\hline \multirow{3}{*}{ 켜 } & Chomurdakhian & $\begin{array}{l}\text { Glyptagnostus stolidotus } \\
\text { Agnostus pisiformis }\end{array}$ & \multirow{3}{*}{ 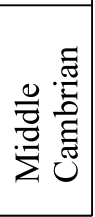 } \\
\hline & Siligirian & $\begin{array}{l}\text { Homagnostus fecundus } \\
\text { Lejopyge laevigata } \\
\text { Aldanaspis truncata }\end{array}$ & \\
\hline & Dzhakhtarian & $\begin{array}{l}\text { Anomocarioides } \\
\text { limbataeformis }\end{array}$ & \\
\hline
\end{tabular}

Figure 5. Stratigraphy of the Cambrian part of the Ogon'or Formation at Khos-Nelege (see location KN in Fig. 1), after Krasnov et al. (1983) and Rozanov et al. (1992).

2000), China (Saltzman et al. 2000; Peng et al. 2004; Zhu et al. 2004), Antarctica (Buggisch, 2006) and Scandinavia (Ahlberg et al. 2006) (Fig. 4). There is some uncertainty, however, in the position of the basal G. reticulatus Biozone with respect to the rising trend of the SPICE excursion (Saltzman et al. 2000). Although the Middle-Upper Cambrian boundary is considered to correspond to the onset of the SPICE excursion, it is situated almost in the middle of the rising trend in its stratotype at Paibi (see Peng et al. 2004, fig. 6; Fig. 4 herein). In Kazakhstan, Australia and Laurentia, the $G$. stolidotus - G. reticulatus boundary is associated with carbon isotope values of $\sim 1 \%$ at the beginning of the rising trend (Saltzman et al. 2000 and Fig. 4 herein).

The two biozones constraining the Middle-Upper Cambrian boundary are now regarded as phylozones, because G. stolidotus is believed to be ancestral to G. reticulatus (Peng et al. 2004). Non-evolutionary changes in trilobite complexes, such as migrations, have been suggested, however, to be common especially at the beginning of the G. reticulatus Biozone (Rozanov et al. 1992). Palmer (1965, 1979) also noted that diachronous boundaries of biostratigraphic units occurred in the Middle and Upper Cambrian, but he later suggested that the difference was not significant for biostratigraphic correlation (Palmer, 1984).

A combined carbon isotopic curve through the Middle-Upper Cambrian strata at Paibi and Wa'ergang sections in South China is provided by Saltzman et al. (2000) (Fig. 4 herein; a vertical arrow in this combined profile indicates a junction between $\delta^{13} \mathrm{C}$ profiles of the Paibi section below and the Wa'ergang section above). Sampling intervals are rather large (several metres to more than $10 \mathrm{~m}$ ), but a more detailed profile comprising 50 samples through the transitional $12 \mathrm{~m}$ at the $G$. stolidotus - G. reticulatus boundary in the Paibi section has been published (Peng et al. 2004). The combined data from South China suggest that the Middle-Upper Cambrian boundary in the stratotype is situated at the beginning of the rising trend of the SPICE excursion. Carbon isotopic values through the transitional strata in Paibi oscillate between $1 \%$ and $2.5 \%$, with the boundary lying at $1.5-2.0 \%$ (Peng et al. 2004, fig. 6) and at $\sim 3 \%$ in Wa'ergang (Saltzman et al. 2000). Values of $\sim 3 \%$ at the level of first appearance of $G$. reticulatus are also reported from the Wangcun section in South China (Zhu et al. 2004).

Based on the position of the SPICE excursion in the Kulyumbe section, the Middle-Upper Cambrian boundary is situated between the base of the Yurakhian Horizon of the Kulyumbe Formation, where carbon isotope values begin to rise, and a level showing values around $\sim 2 \%$ at the top of section 6 (Figs 1 , 2). The position of the Middle-Upper Cambrian boundary, traced to the boundary between the Labaz and Orakta formations according to the local trilobite biostratigraphy, is thus $\sim 700 \mathrm{~m}$ lower than that indicated by chemostratigraphy. Therefore, biostratigraphic correlation of the basal Orakta Formation with the $G$. reticulatus Biozone at Khos-Nelege is unlikely correct.

A worldwide mass extinction of trilobites at the base of the Glyptagnostus reticulatus Biozone marks the beginning of the SPICE excursion (Saltzman et al. 2000). Eighty species from the Glyptagnostus stolidotus zone do not proceed into the G. reticulatus Biozone in Laurentia. The diversity of trilobites increases later, during the rising trend of SPICE. In the Kulyumbe section the diversity of trilobites declines from the Labaz Formation (upper Middle Cambrian) towards the Cambrian-Ordovician boundary, with the most dramatic decline in number of species taking place in the upper Orakta Formation (Fig. 2; Table 5 of Supplementary Material). Trilobite complexes show significant renewal through each boundary between biozones and horizons in the section, including the Middle-Upper Cambrian boundary transition identified herein by chemostratigraphy at the base of the Yurakhian Horizon. The trilobite fauna of the Yurakhian Horizon is completely renewed with respect to that of the Entsian Horizon (Fig. 2), but in contrast with data from Saltzman et al. (2000), there is no evidence for increase in diversity during the rising trend of the SPICE excursion in the Kulyumbe section. Although new species and genera of trilobites continue to appear throughout the Kulyumbe Formation (Datsenko et al. 1968; Rozova, 1968, 1984), the diversity generally declines (Fig. 2; Table 5 of Supplementary Material). The trilobites from the Kulyumbe section are endemic forms (Rozova, 1963, 1964, 1968, 1984; Rozanov et al. 1992; Sukhov, 1997; Varlamov, Pak \& Rozova, 2006), and therefore their evolutionary pattern and diversity changes differ from those of forms with global distribution. Hence, the 
observed decline in diversity at Kulyumbe could be related to local palaeogeography and environments.

\section{The Cambrian-Ordovician boundary in the Kulyumbe section}

There are two distinct proposals for how to correlate the Kulyumbe section with the base of the Ordovician System. The first one places the Cambrian-Ordovician boundary on the Siberian Platform at the base of the Mansian Horizon (Krasnov et al. 1983; Fig. 2). In the second one (Rozova, 1968, 1984), the boundary is positioned at the base of the Nyajan Horizon. The latter option was supported by the Cambrian-Ordovician boundary International Working Group in 1986 (Fig. 2).

A lower boundary of the Ordovician System was finally ratified by the Cambrian-Ordovician boundary International Working Group at the base of the Tremadocian Stage at Green Point in western Newfoundland, where it was defined by the first appearance of the conodont Iapetognathus fluctivagus (Cooper \& Nowlan, 1999). Thus, the occurrence of Cordylodus proavus can now be used to assign the Loparian and Mansian horizons to the Upper Cambrian (Dubinina, 2000; Tesakov et al. 2003). The Ordovician $C$. angulatus was found in the Nyajan Horizon (Tesakov et al. 2003), but taxonomic revision of Siberian Cordylodus species is still needed (Tatiana Tolmacheva, pers. comm. 2006).

Although the carbon isotopic record from the Cambrian-Ordovician boundary stratotype at Green Point seems to be distorted by diagenesis (Cooper, Nowlan \& Williams, 2001), a combination of data from other sections, such as Dayangcha in China (Ripperdan, Magaritz \& Kirschvink, 1993), Black Mountain in Australia (Ripperdan et al. 1992; Miller et al. 2006) and Lawson Cove in Utah (Ripperdan \& Miller, 1995; Miller et al. 2006) enabled a generalized (global) curve to be compiled (Cooper, Nowlan \& Williams, 2001, fig. 4; Fig. 4 herein). The Cambrian-Ordovician boundary is marked by the highest $\delta^{13} \mathrm{C}$ value of the transitional interval, in the Iapetognathus Biozone, before the value decreases through the $C$. angulatus Biozone (Cooper, Nowlan \& Williams, 2001). There are also two main positive cycles below this excursion, between the base of the Cordylodus proavus and the base of the $C$. lindstromi biozones (Ripperdan \& Miller, 1995; Cooper, Nowlan \& Williams, 2001, fig. 4; Miller et al. 2006).

A Lower-Middle Ordovician carbon isotopic curve of high resolution and biostratigraphically constrained by Laurentian conodont biozones was published by Buggisch, Keller \& Lehnert (2003) from an isolated terrane of probable Laurentian provenance in Argentina. However, there are no species of Iapetognatus and Cordylodus known from that section, probably because of unfavourable facies. The SPICE excursion is also missing from that profile, because of a stratigraphic hiatus. The lower and upper boundaries of the Tremadocian Stage are marked by falling values from local maxima at the Cambrian-Ordovician boundary and in the upper Tremadocian (see Buggisch, Keller \& Lehnert, 2003, fig. 6). A single positive excursion of $2 \%$ amplitude (from $-1 \%$ to $1 \%$ ) in the R. manitouensis Biozone is unknown beyond Argentina owing to lack of data from this stratigraphic interval (Buggisch, Keller \& Lehnert, 2003). Otherwise, the Upper Cambrian-Tremadocian portion of this curve can be satisfactorily correlated with other transitional profiles (Buggisch, Keller \& Lehnert, 2003; Fig. 4 herein).

There are apparently three positive excursions and four troughs above SPICE in the Kulyumbe section (Fig. 2). The lower maximum is situated in the lower Khetian Horizon of the Kulyumbe Formation ('postSPICE' excursion in Fig. 2). It is similar in position and magnitude to a reported positive $\delta^{13} \mathrm{C}$ feature with an amplitude up to $2 \%$ observed immediately above the SPICE excursion in Laurentia, above the last occurrence of Irvingella (Saltzman, 2001), and above the Ivshinagnostus ivshini Biozone in Kazakhstan (Saltzman et al. 2000). The subsequent decrease in values coupled with the SPICE excursion is recognized as the HERB event, a Sunwaptan-aged negative $\delta^{13} \mathrm{C}$ anomaly identified in Australia and Laurentia (Ripperdan et al. 1992; Ripperdan, 2002; Miller et al. 2006). It is represented by minimum values of $-3 \%$ to $-4 \%$ in Australia (Ripperdan et al. 1992; Miller et al. 2006; Fig. 4) or a less pronounced trough in Laurentia (Buggisch, Keller \& Lehnert, 2003; Saltzman et al. 2004; Miller et al. 2006; Fig. 4). Buggisch, Keller \& Lehnert (2003) suggested, however, that negative anomalies, such as HERB, could have been produced or enhanced by diagenesis at sequence boundaries rather than representing the true magnitudes of primary oceanic carbon reservoir changes. Although more pronounced, the HERB minimum can be tentatively correlated to an isotopic minimum of $-1 \%$ at the boundary between the Kulyumbe and Ujgur formations (HERB? in Figs 2, 4). The location of these features in the Khetian Horizon is consistent with its terminal Upper Cambrian affinity.

At least two more peaks appear in the Kulyumbe section, within the Ujgur and Iltyk formations. Through a combination of chemostratigraphy and biostratigraphy, a lowermost possible and a most probable position of the Cambrian-Ordovician boundary in Kulyumbe may be indicated. The upper portion of the Iltyk Formation is referred to as the Ugorian Horizon (not shown here) and tentatively attributed to the 'Arenig Stage' of the Lower Ordovician (Rozanov et al. 1992). According to biostratigraphy, the lower Tremadocian boundary is situated below the Ugorian Horizon. On the other hand, based on the available chemostratigraphic information, the Cambrian-Ordovician boundary is unlikely to be situated at the base of the Mansian Horizon because of a well-defined isotopic trough there (HERB? in Figs 2, 4). Two intervals in the Kulyumbe profile may therefore be suggested for potential placement of the 

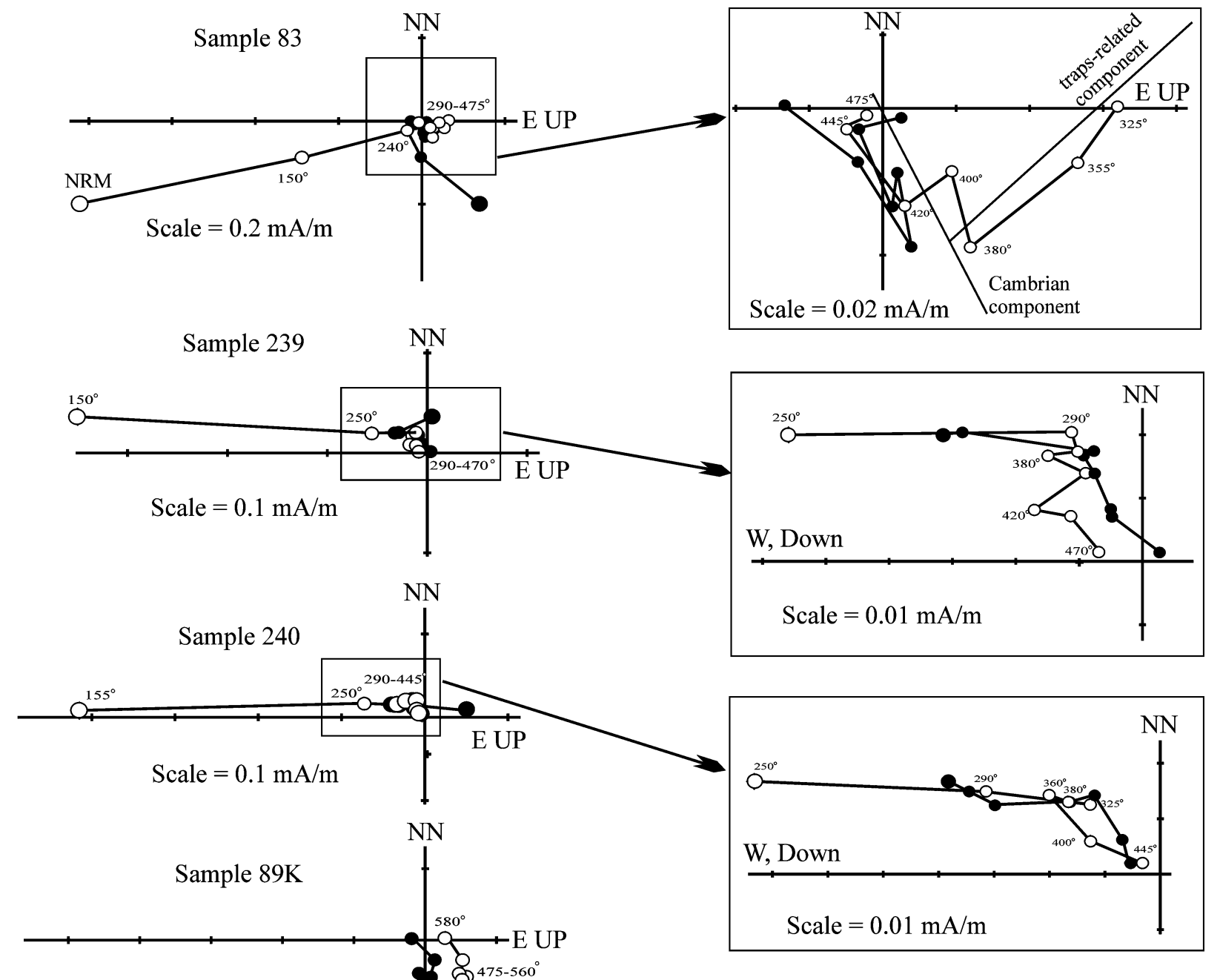

a
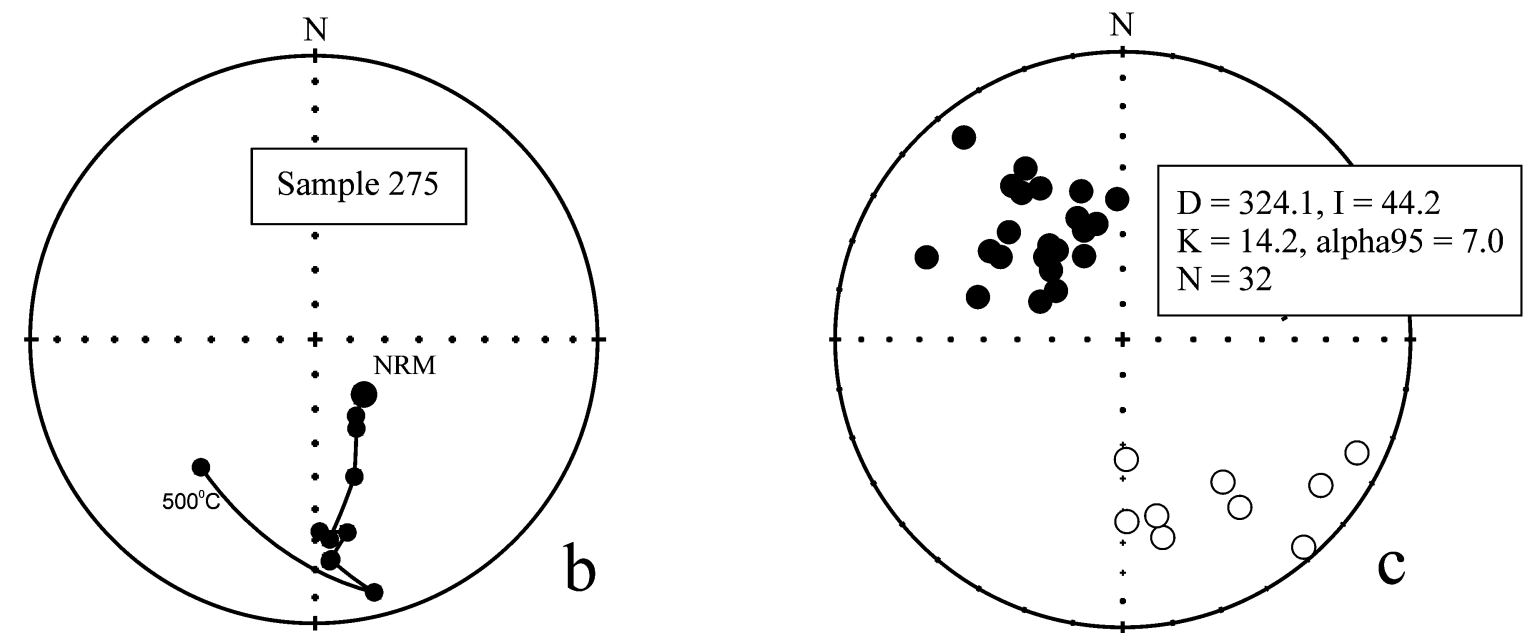

Figure 6. (a) Zijderveld diagrams; open (solid) circles - projections on vertical (horizontal) plane. (b) Demagnetization behavior of natural remnant magnetization which indicates the normal polarity of the characteristic component; solid circles - projections on lower hemisphere. (c) Distribution of isolated directions of the characteristic component (stratigraphic system of coordinates); solid (open) circles - projections on lower (upper) hemisphere.

Cambrian-Ordovician boundary: the upper Mansian and the upper Loparian-middle Nyajan horizons. The upper Mansian isotopic maximum represents the first local maximum after the post-SPICE and HERB? excursions, and its position is therefore regarded to be too low for the Cambrian-Ordovician boundary (Figs 2, 4). A more probable location for this boundary lies within the upper Loparian-middle Nyajan interval, 
but the positive excursion there may be composite, since values oscillate throughout these beds, and the isotopic signature may be insufficiently resolved owing to larger sampling intervals (Figs 2, 4). Nevertheless, a fall in carbon isotope values in the upper Nyajan Horizon and its biostratigraphic correlation with the lowermost Ordovician (Dubinina, 2000; Tesakov et al. 2003) is consistent with our proposition that the most probable position of the Cambrian-Ordovician boundary at Kulyumbe is in the middle part of the Nyajan Horizon, in outcrop 7322 (Figs 1, 2, 4).

\section{Strontium isotopic interpretation}

Our data imply a subtle rise in seawater ${ }^{87} \mathrm{Sr} /{ }^{86} \mathrm{Sr}$ from the Middle Cambrian to the middle of the Late Cambrian. This rise might continue to all-time high values for the Phanerozoic, possibly as high as 0.70920 , as recorded in the slightly younger upper Pterocephaliid biomere in the USA (Saltzman et al. 1995). Published micrite and conodont ${ }^{87} \mathrm{Sr} /{ }^{86} \mathrm{Sr}$ data show a subsequent decrease across the Cambrian-Ordovician boundary worldwide, from 0.70910 to 0.70900 (Saltzman et al. 1995; Ebneth et al. 2001). Strontium isotope ratios were as high during the Middle-Late Cambrian as they are today, and possibly even higher (Saltzman et al. 1995; Montañez et al. 2000), which indicates a unique importance during that time of chemical weathering on ocean composition relative to that of submarine hydrothermal exchange with juvenile ocean crust (Ebneth et al. 2001). The unique situation during late Cambrian times is underscored by the fact that the ${ }^{87} \mathrm{Sr} /{ }^{86} \mathrm{Sr}$ ratio of carbonate rocks undergoing weathering and that of the depleted mantle would have been considerably lower than today, thus pushing seawater ${ }^{87} \mathrm{Sr} /{ }^{86} \mathrm{Sr}$ to lower, rather than higher, values. The high ${ }^{87} \mathrm{Sr} /{ }^{86} \mathrm{Sr}$ of the late Cambrian ocean has been attributed to elevated chemical weathering rates of crustal silicate minerals uplifted during the Pan-African (Montañez et al. 2000) and Transgondwanan orogenies (Squire et al. 2006).

\section{Palaeomagnetism}

The detailed magnetostratigraphic log of the Kulyumbe section presented herein (Fig. 2) combines published magnetostratigraphic columns for the Middle Cambrian-Lower Ordovician interval (Pavlov \& Gallet, 1998, 2001), corrected, refined and complemented with additional data from the Orakta Formation (Table 1 of Supplementary Material).

Additional sampling in 1998 from the lower part of the Entsian Horizon revealed three intervals of normal polarity instead of the two reported by Pavlov \& Gallet (1998) (see Pavlov \& Gallet, 2005, fig. 4; Fig. 2 herein). There are also two new very narrow reversed-polarity zones confirmed only by single samples from the lower Loparian Horizon (sample K294) and the middle Labaz Formation (sample 410), as well as several narrow polarity intervals in the middle Labaz Formation, mostly based on single samples (among samples 531846). New and corrected polarity intervals are indicated by arrows in Figure 2 (see also comments in Table 1 of Supplementary Material). Polarity zones represented by a single sample only are shown by half bars in the magnetostratigraphic column in Figure 2 and Table 1 of the Supplementary Material. They await confirmation after more detailed sampling. Most of the sampling gaps larger than $10 \mathrm{~m}$ are shown in the new version of magnetostratigraphic column by hiatuses (Fig. 2).

Data from the Orakta Formation were obtained from samples collected in 1998 and yielded a very weak and noisy palaeomagnetic signal. Isolation of characteristic palaeomagnetic components from most of these samples was either impossible or very difficult. Nevertheless, some samples show a palaeomagnetic two-component record (Fig. 6a) suggesting a direction of the characteristic magnetization (Fig. 6c). Some samples show three components of magnetization: less stable, recent (low-temperature) and traps-related (middle-temperature) ones, and a more stable, characteristic (high-temperature) component. The mean palaeomagnetic direction of the isolated characteristic component is close to that which is well defined from the Labaz and Kulyumbe formations. Some samples from the Orakta Formation do not allow determination of the direction of the characteristic component (Fig. 6b), but their behaviour during analyses indicates the polarity of the ancient magnetization (marked 'great circle' in Table 1 of Supplementary Material). Given the overall low quality of the palaeomagnetic record in the Orakta Formation, a corresponding polarity sequence needs to be confirmed by data from other sections and should therefore be considered as preliminary (indicated as 'low quality signal' in Fig. 2).

Thus, a succession of 19-20 magnetic intervals from the Orakta and lower Kulyumbe formations can probably be added to 54-80 intervals previously reported by Pavlov \& Gallet (2005) from the Middle Cambrian of Siberia. This number is again a minimum estimate, as many magnetic intervals have a small stratigraphic thickness of less than $1 \mathrm{~m}$ and are based on single samples. Our combined results confirm observations (Pavlov \& Gallet, 2001; Gallet, Pavlov \& Courtillot, 2003) that during the Middle Cambrian the geomagnetic reversal frequency was as high as 7-10 reversals per Ma, assuming a total duration of about $10 \mathrm{Ma}$ and up to 100 magnetic intervals in the Middle Cambrian. By contrast, the sequence attributed herein to the Upper Cambrian on the grounds of chemostratigraphic correlation contains only 10-11 magnetic intervals, whereas there are 2-3 intervals in the lowermost Ordovician (lower Tremadocian) part (Fig. 2). Hence, magnetostratigraphic data from the Upper Cambrian strata of the Kulyumbe section obtained by Pavlov \& Gallet (1998) and adjusted herein show a one-order-of-magnitude lower number and frequency of magnetic reversals than in the Middle Cambrian. 
Upper Cambrian-Lower Ordovician magnetostratigraphic results from several sections, such as the Black Mountain in Australia (Ripperdan et al. 1992), Dayangcha (Ripperdan, Magaritz \& Kirschvink, 1993) and Tangchan (Yang et al. 2002) in China, Green Point in western Newfoundland, Bartyrbay in Kazakhstan, and from Texas (Ripperdan \& Kirschvink, 1992) do not, however, provide a standardized magnetostratigraphic scale through the Cambrian-Ordovician interval (Cooper, Nowlan \& Williams, 2001). A tentative correlation of magnetostratigraphic zones of the Upper Cambrian-Lower Ordovician of China and Australia with the Kulyumbe section was suggested by Pavlov \& Gallet (2005). It has been also reported that in general the geomagnetic field had a predominantly reversed polarity through the Cambrian-Ordovician boundary interval, but with episodes of normal polarity in the late Proconodontus, late Eoconodontus biozones of the Upper Cambrian and in the Early Ordovician (Cooper, Nowlan \& Williams, 2001). As for the Middle Cambrian and most of the Upper Cambrian, palaeomagnetic zonation is known only from the Siberian Platform (Pavlov \& Gallet, 1998, 2001, 2005; this study).

\section{Conclusions}

The global SPICE excursion with amplitude of about $+5 \%$ is found in the Yurakhian Horizon, in the middle part of the Kulyumbe Formation (Fig. 2). It terminates an interval with low-amplitude carbon isotope oscillations in the Middle Cambrian upper Mayan Stage of Siberia. According to the position of the SPICE excursion in the Kulyumbe section, the Middle-Upper Cambrian boundary is placed within an interval no lower then the base of the Yurakhian Horizon of the Kulyumbe Formation.

A fall of carbon isotope values in the upper Nyajan Horizon agrees with its biostratigraphic correlation with the lowermost Ordovician conodont biozones and is consistent with a proposition herein that the most probable position for the Cambrian-Ordovician boundary would be in the middle portion of the Nyajan Horizon.

Our integrated isotopic study further confirms some intriguing aspects of the Late Cambrian ocean, when a major global positive $\delta^{13} \mathrm{C}$ excursion (SPICE) coincided with all-time maximum ${ }^{87} \mathrm{Sr} /{ }^{86} \mathrm{Sr}$ values in marine carbonates. High ${ }^{87} \mathrm{Sr} /{ }^{86} \mathrm{Sr}$ ratios in seawater during this interval may relate to uniquely high rates of chemical weathering on the continent.

A continuous reversed polarity interval is observed through the SPICE event with a zone of normal polarity near the Middle-Upper Cambrian boundary (Fig. 2). The frequency of reversals in the Upper Cambrian was about one order of magnitude lower than in the Middle Cambrian. The magnetic polarity sequence presented here further supports the conclusion (Pavlov \& Gallet, 2001; Gallet, Pavlov \& Courtillot, 2003) that the geomagnetic reversal frequency was very high during the Middle Cambrian, probably the highest in Phanerozoic times.

Acknowledgements. We acknowledge support from the NASA Astrobiology Institute and the Swedish Research Council (Grant no. 621-2001-1751 to Stefan Bengtson and Grant no. 623-2003-207 to Artem Kouchinsky). Artem Kouchinsky is also supported from the NordCEE (Nordic Center for Earth Evolution) project (Danish National Research Foundation (Danmarks Grundforskningsfond)) grant to Prof. Donald Canfield. Yves Gallet and Vladimir Pavlov acknowledge support from Institut de Physique du Globe de Paris (IPGP contribution no. 2358) and the Russian Foundation for Fundamental Research (grant RFBR no. 0705-00880) respectively. Graham Shields gratefully acknowledges the financial support of the Alexander von Humboldt Foundation during 2006 and 2007. Financial support of Stefan Ebneth was from the Leibniz Prize endowment of Deutsche Forschungsgemeinschaft to Jan Veizer. We thank Stefan Ohlsson, Klara Hajnal and Peter Torssander (Stockholm) and Dieter Buhl (Bochum) for technical assistance with sample preparation, elemental and isotope analyses and Stefan Ebneth (Bochum) for the reconnaissance study and sampling. The authors are grateful to both anonymous reviewers for their critical comments on the manuscript. Supplementary Material Tables 1 through 5 are available online at http://doi.pangaea.de/10.1594/PANGAEA.687608 and at http://www.cambridge.org/journals/geo.

\section{References}

Ahlberg, P., Axheimer, N., ERIKSson, M. E., Schmitz, B. \& Terfelt, F. 2006. High-resolution trilobite biostratigraphy and carbon isotope stratigraphy of the middle Cambrian-lower Furongian of Baltica. In 11th International conference of the Cambrian Stage Subdivision Working Group, South Australia, August 14 24, 2006, Abstracts 84 (ed. J. B. Jago), p. 5. Geological Society of Australia.

Babcock, L. E., Peng, S., Geyer, G. \& Shergold, J. H. 2005. Changing perspectives on Cambrian chronostratigraphy and progress toward subdivision of the Cambrian System. Geosciences Journal 9(2), 101-6.

BRASIER, M. D. \& SUKHOV, S. S. 1998. The falling amplitude of carbon isotopic oscillations through the Lower to Middle Cambrian: northern Siberia data. Canadian Journal of Earth Sciences 35, 353-73.

BugGisch, W. 2006. Stable carbon isotopes of the Late Cambrian Minaret Formation, Ellsworth mountains, West Antarctica. Scientific Committee on Antarctic Research Open Science Conference, July 12-14. Hobart, Tasmania. Abstract, p. 210.

BugGisch, W. In press. Carbon isotope record of Middle Cambrian to Late Silurian carbonate and shale of Northeastern Ellesmere Island. Bulletin of the Canadian Geological Survey.

Buggisch, W., Keller, M. \& Lehnert, O. 2003. Carbon isotope record of Late Cambrian to Early Ordovician carbonates of the Argentine Precordillera. Palaeogeography, Palaeoclimatology, Palaeoecology 195, 357-73.

CoOPer, R. A. \& Nowlan, G. 1999. Proposed global Stratotype Section and Point for base of the Ordovician System. In Quo vadis Ordovician? (eds P. Kraft and O. Fatka), pp. 61-4. Short papers of the 8th International Symposium on the Ordovician System. Acta Universitatis Carolinae, Geologica 43. 
CoOper, R. A., Nowlan, G. S. \& Williams, S. H. 2001. Global Stratotype Section and Point for base of the Ordovician System. Episodes 24, 19-28.

Datsenko, V. A., ZhuraVleva, I. T., Lazarenko, N. P., Popov, Yu. N. \& Chernysheva, N. E. 1968. Biostratigrafiya i fauna kembrijskikh otlozhenij severozapada Sibirskoj platformy. (Biostratigraphy and fauna of the Cambrian deposits of northwestern Siberian platform). Transactions of the Scientific Research Institute of the Geology of the Arctic (NIIGA) 155, $242 \mathrm{pp}$.

DubininA, S. V. 2000. Conodonts and zonal stratigraphy of the Cambrian-Ordovician boundary deposits. Transactions of the Geological Institute of the Russian Acadaemy of Sciences 517. Moscow: Nauka, 239 pp. (in Russian).

EbNeth, S., Shields, G. A., Veizer, J., Miller, J. F. \& SHERGOLD, J. 2001. High-resolution strontium isotope stratigraphy across the Cambrian-Ordovician transition. Geochimica et Cosmochimica Acta 65, 2273-92.

Gallet, Y., Pavlov, V. \& Courtillot, V. 2003. Magnetic reversal frequency and apparent polar wander of the Siberian platform in the earliest Palaeozoic, inferred from the Khorbusuonka river section (northeastern Siberia). Geophysical Journal International 154, 82940.

Geyer, G. \& Shergold, J. 2000. The quest for internationally recognized divisions of Cambrian time. Episodes 23, 188-95.

GlumaC, B. \& WalkeR, K. R. 1998. A Late Cambrian positive carbon-isotope excursion in the Southern Appalachians: Relation to biostratigraphy, sequence stratigraphy, environments of deposition, and diagenesis. Journal of Sedimentary Research 68, 1212-22.

KAMPSCHUlte, A. \& StRAUSS, H. 2004. The sulfur isotopic evolution of Phanerozoic seawater based on analysis of structurally substituted sulfate in carbonates. Chemical Geology 204, 255-86.

Kaufman, A. J. \& KnOll, A. H. 1995. Neoproterozoic variations in the $\mathrm{C}$-isotopic composition of seawater: Stratigraphic and biogeochemical implications. Precambrian Research 73, 27-49.

Krasnov, V. I., SAVITSKY, V. E., Tesakov, Yu. I. \& Khomentovsky, V. V. (eds) 1983. Decrees of the AllUnion Stratigraphical Meeting on the Precambrian, Paleozoic and Quaternary Systems of Middle Siberia, Novosibirsk, 1979, Part 1 (Upper Proterozoic and Lower Paleozoic). Leningrad, USSR: Cartographic Publishing House of All-Union Geological Institute, 216 pp. (in Russian).

Lazarenko, N. P. \& Pegel', T. V. 2001. Upper Cambrian levels of biostratigraphical correlation in the KhosNelege River reference section (northeastern flank of the Siberian platform). In Cambrian System of South China (eds S. Peng, L. E. Babcock \& M. Zhu.), 276-9. Palaeoworld 13. Hefei: Press of University of Science and Technology of China.

Miller, J. F., Ethington, R. L., Evans, K. R., Holmer, L. E., Loch, J. D., Popov, L. E., RePeTSKI, J. E., RIPPERDAN, R. L. \& TAYLOR, J. F. 2006. Proposed stratotype for the base of the highest Cambrian stage at the first appearance datum of Cordylodus andresi, Lawson Cove section, Utah, USA. Palaeoworld 15(34), 384-405.

Montañez, I. P., Osleger, D. A., BAnNer, J. L., MACK, L. E. \& Musgrove, M. 2000. Evolution of the Sr and C Isotope Composition of Cambrian Oceans. GSA Today 10, 1-7.
Palmer, A. R. 1965. Trilobites of the Late Cambrian Pterocephaliid Biomere in the Great Basin, United States. Geological Survey Professional Paper 493, 105 pp.

PALMER, A. R. 1979. Biomere boundaries re-examined. Alcheringa 3, 33-41.

PALMER, A. R. 1984. The Biomere problem: evolution of an idea. Journal of Paleontology 58, 599-611.

PAVlov, V. \& GALlet, Y. 1998. Upper Cambrian to Middle Ordovician magnetostratigraphy from the Kulumbe river section (northwestern Siberia). Physics of the Earth and Planetary Interiors 108, 49-59.

PAVlov, V. \& Gallet, Y. 2001. Middle Cambrian high magnetic reversal frequency (Kulumbe River section, northwestern Siberia) and reversal behaviour during the Early Palaeozoic. Earth and Planetary Science Letters 185, 173-83.

PAVLOV, V. \& GALLET, Y. 2005. Third superchron during the Early Paleozoic. Episodes 28, 78-84.

Peng, S., BABCOCK, L. E., Robison, R. A., Lin, H., ReES, M. N. \& Saltzman, M. R. 2004. Global Standard Stratotype-section and Point (GSSP) of the Furongian Series and Paibian Stage (Cambrian). Lethaia 37, 365-79.

Peng, S., BABCOCK, L. E., ZuO, J., LIN, H., ZHU, X., YANG, X., Robison, R. A., QI, Y., BAgnoli, G. \& CHEN, Y. 2006. Proposed GSSP for the base of Cambrian Stage 7, coinciding with the first appearance of Lejopyge laevigata, Hunan, China. Palaeoworld 15(3-4), 367-83.

RIPPERDAN, R. 2002. The HERB event: end of the Cambrian carbon cycle paradigm? Geological Society of America Abstracts with Programs 34(6), 413.

RIPPERDAN, R. L. \& KIRSCHVINK, J. L. 1992. Paleomagnetic results from the Cambrian-Ordovician boundary section at Black Mountain, Georgina Basin, western Queensland, Australia. In Global Perspectives on Ordovician Geology (eds B. D. Webby \& J. R. Laurie.), pp. 381-94. Rotterdam: A. A. Balkema.

RiPPERDAN, R. L., MAGARITZ, M. \& KirSCHVINK, J. L. 1993. Carbon isotope and magnetic polarity evidence for nondepositional events within the Cambrian-Ordovician boundary section near Dayangcha Jilin Province, China. Geological Magazine 130, 443-52.

RipPERdAN, R. L., MAGARITZ, M., Nicoll, R. S. \& SHERGOLD, J. H. 1992. Simultaneous changes in carbon isotopes, sea level, and conodont biozones within the Cambrian-Ordovician boundary interval at Black Mountain, Australia. Geology 20, 1039-42.

RIPPERDAN, R. L. \& MILLER, J. F. 1995. Carbon isotope ratios from the Cambrian- Ordovician boundary section at Lawson Cove, Ibex area, Utah. In Ordovician Odyssey: short papers for the Seventh International Symposium on the Ordovician System (eds J. D. Cooper, M. L. Droser \& S. C. Finney.), pp. 129-32. Pacific Section of Economic Paleontologists and Mineralogists, Special Publication no. 77.

Rozanov, A. Yu., Repina, L. N., Apollonov, M. K., Shabanov, Yu. Ya., ZhuraVleV, A. Yu., Pegel', T. V., FEDOROV, A. B., AstashKIN, V. A., ZhURAVlEVA, I. T., Egorova, L. I., Chugaeva, M. N., DubininA, S. V., ERMAK, V. V., ESAKOVA, N. V., SUNDUKOV, V. V., SuKHOV, S. S. \& ZHEMCHUZHNIKOV, V. G. 1992. Kembrij Sibiri. (The Cambrian of Siberia). Novosibirsk: Nauka, $135 \mathrm{pp}$.

RozovA, A. V. 1963. Biostratigraficheskaya skhema raschleneniya verkhnego i verkhov srednego kembriya severo-zapada Sibirskoj platformy i novye verkhnekembrijskie trilobity r. Kulyumbe. (Biostratigraphic scheme of subdivisions of the Upper - upper Middle Cambrian in the northwestern Siberian platform and 
new Upper Cambrian trilobites of the Kulyumbe River). Geologiya i geofizika 9, 3-19 (in Russian).

Rozova, A. V. 1964. Biostratigrafiya i opisanie trilobitov srednego i verkhnego kembriya severo-zapada Sibirskoj platformy. (Biostratigraphy and description of trilobites of the Middle and Upper Cambrian of the northwestern Siberian platform). Institute of Geology and Geophysics. Novosibirsk: Academy of Sciences of the USSR, Siberian Division, 148 pp. (in Russian).

RozovA, A. V. 1968. Biostratigrafiya i trilobity verkhnego kembriya i nizhnego ordovika severo-zapada Sibirskoj platformy. (Biostratigraphy and trilobites of the Upper Cambrian and Lower Ordovician of the northwestern Siberian platform). Institute of Geology and Geophysics. Novosibirsk: Academy of Sciences of the USSR, Siberian Division, 196 pp. (in Russian).

RozovA, A. V. 1984. Biostratigraphic zoning and trilobites of the Upper Cambrian and Lower Ordovician of the northwestern Siberian platform. New Delhi: Amerind Publishing Co. Pvt. Ltd., 279 pp. (translated from Rozova, A. V. 1968).

RozovA, A. V. \& YADRENKINA, A. G. 1967. Biostratigrafiya i brakhiopody verkhnego kembriya i nizhnego ordovika razreza r. Kulyumbe (Sibirskaya platforma). (Biostratigraphy and brachiopods of the Upper Cambrian and Lower Ordovician of the Kulyumbe River section (Siberian Platform)). Novye dannye po biostratigrafii nizhnego paleozoya Sibirskoj platformy. (New data on the biostratigraphy of the Lower palaeozoic of the Siberian Platform). Moscow: Nauka, 12-44. (in Russian)

SALTZMAN, M. R. 2001. Carbon isotope stratigraphy of the Upper Cambrian Steptoean Stage and equivalents worldwide. Palaeoworld 13, 299.

SAltZMAN, M. R. 2005. Phosphorus, nitrogen, and the redox evolution of the Paleozoic oceans. Geology 33, 573-6.

SaltzMan, M. R., Cowan, C. A., Runkel, A. C., RunNegar, B., STEWART, M. C. \& PALMER, A. R. 2004. The Late Cambrian SPICE $\left(\delta^{13} \mathrm{C}\right)$ event and the SAUK II-SAUK III regression: new evidence from Laurentian basins in Utah, Iowa, and Newfoundland. Journal of Sedimentary Research 74, 366-77.

SALTZMAN, M. R., DAVIDSON, J. P., HOLDEN, P., RUNNEGAR, B. \& LoHmanN, K. C. 1995. Sea-level-driven changes in ocean chemistry at an Upper Cambrian extinction horizon. Geology 23, 893-6.

SAltzMan, M. R., RiPPERdAN, R. L., Brasier, M. D., Lohmann, K. C., Robinson, R. A., Chang, W. T., Peng, S., Ergaliev, E. K. \& Runnegar, B. R. 2000. A global carbon isotope excursion (SPICE) during the Late Cambrian: Relation to trilobite extinctions, organic-matter burial and sea level. Palaeogeography, Palaeoclimatology, Palaeoecology 160, 211-23.

Saltzman, M. R., Runnegar, B. R. \& Lohmann, K. C. 1998. Carbon isotope stratigraphy of Upper Cambrian (Steptoean Stage) sequences of the eastern Great Basin: Record of a global oceanographic event. Geological Society of America Bulletin 110, 285-97.

Shabanov, Yu. Ya., SAVITSKY, V. E. \& ChERnYSheVA, N. E. 1967. Biostratigrafiya majskogo yarusa Igarskogo rajona. (Biostratigraphy of the Mayan Stage of the Igarka region.) SNIIGGiMS Transactions 55.

ShieldS, G. A., Carden, G. A. F., Veizer, J., Meidla, T., RoNG, J.-Y. \& LI, R.-Y. 2003. Sr, C and O isotope geochemistry of Ordovician brachiopods: a major isotopic event around the Middle-Late Ordovician transition. Geochimica et Cosmochimica Acta 67, 2005 25 .

SoKOLOV, B. S. (ed.) 1982. Ordovician of the Siberian Platform: key section on the Kulumbe River. Novosibirsk: Nauka, 118 pp. (in Russian).

Squire, R. J., CAMPBell, I. H., Allen, C. M. \& Wilson, C. J. L. 2006. Did the Transgondwanan Supermountain trigger the explosive radiation of animals on Earth? Earth and Planetary Science Letters 250, 116-33.

SukHov, S. S. 1997. Cambrian depositional history of the Siberian craton: evolution of the carbonate platforms and basins. Sedimentary Facies and Palaeogeography 17, 27-39.

Tesakov, Yu. I., Kanygin, A. V., Yadrenkina, A. G., Simonov, O. N., SycheV, O. V., Abaimova, G. P., Divina, T. A. \& MoskalenKo, N. A. 2003. Ordovician of the northwestern Siberian platform. Novosibirsk: Publishing House of the Siberian Division of the Russian Academy of Sciences, 364 pp. (in Russian).

Varlamov, A. I., PaK, K. L. \& Rozova, A. V. 2006. The Upper Cambrian of the Chopko River section, Norilsk region, northwestern Siberian platform: Stratigraphy and trilobites. Paleontological Journal 40, Supplement $1, \mathrm{~S} 1-\mathrm{S} 56$.

YANG, Z., Otofuji, Y., Sun, Z. \& HuAnG, B. 2002. Magnetostratigraphic constraints on the Gondwanan origin of North China: Cambrian/Ordovician boundary results. Geophysical Journal International 151, 1-10.

ZhU, M., ZHANG, J., LI, G. \& YANG, A. 2004. Evolution of $\mathrm{C}$ isotopes in the Cambrian of China: Implications for Cambrian subdivision and trilobite mass extinctions. Geobios 37, 287-310.

Zhu, M., BABCock, L. E. \& Peng, S. 2006. Advances in Cambrian stratigraphy and paleontology: Integrating correlation techniques, paleobiology, taphonomy and paleoenvironmental reconstruction. Palaeoworld 15(34), 217-22. 